Old Dominion University

ODU Digital Commons

English Faculty Publications

English

2011

\title{
Whitewash: Nationhood, Empire, and the Formation of Portuguese Racial Identity
}

Manuela Mourao

Old Dominion University, mmourao@odu.edu

Follow this and additional works at: https://digitalcommons.odu.edu/english_fac_pubs

Part of the Ethnic Studies Commons, European History Commons, and the Race and Ethnicity Commons

\section{Repository Citation}

Mourao, Manuela, "Whitewash: Nationhood, Empire, and the Formation of Portuguese Racial Identity" (2011). English Faculty Publications. 44.

https://digitalcommons.odu.edu/english_fac_pubs/44

\section{Original Publication Citation}

Mourao, M. (2011). Whitewash: Nationhood, empire, and the formation of Portuguese racial identity. Journal for Early Modern Cultural Studies, 11(1), 90-124.

This Article is brought to you for free and open access by the English at ODU Digital Commons. It has been accepted for inclusion in English Faculty Publications by an authorized administrator of ODU Digital Commons. For more information, please contact digitalcommons@odu.edu. 
Whitewash: Nationhood, Empire, and the Formation of Portuguese Racial Identity Authors(s): MANUELA MOURÃO

Source: Journal for Early Modern Cultural Studies, Vol. 11, No. 1 (Spring/Summer 2011), pp. 90-124

Published by: University of Pennsylvania Press

Stable URL: http://www.jstor.org/stable/23242189

Accessed: 25-03-2016 19:26 UTC

Your use of the JSTOR archive indicates your acceptance of the Terms \& Conditions of Use, available at

http://about.jstor.org/terms

JSTOR is a not-for-profit service that helps scholars, researchers, and students discover, use, and build upon a wide range of content in a trusted digital archive. We use information technology and tools to increase productivity and facilitate new forms of scholarship. For more information about JSTOR, please contact support@jstor.org.

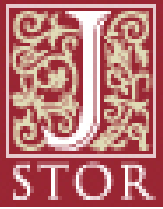

Indiana University Press, University of Pennsylvania Press are collaborating with JSTOR to digitize, preserve and extend access to Journal for Early Modern Cultural Studies

http://www.jstor.org 


\title{
Whitewash:
}

\author{
Nationhood, Empire, and the Formation \\ of Portuguese Racial Identity
}

MANUELA MOURÃo

\begin{abstract}
A B S T R A C T
This article analyzes the origins and development of Portuguese racial identity as reflected in chronicles of the Portuguese first contacts with Africa and the East and in the context of the nation's cultural history. Starting in the late 1400s with the arrival of Vasco da Gama's ships in India, and continuing well into the sixteenth century with the establishment of commercial outposts along a number of coastal areas in the Indian Ocean, the interaction between the Portuguese and the nonWestern world bad a significant impact on the cultures of all nations involved-and, this article contends, on the formation of racial categories that endure today. Scholars of European history have recently begun to emphasize the need to probe further the concepts of race in early modern Europe in an effort to deepen our understanding of racial thought both at the time and today. This essay contributes to this effort by offering a study of the formation of Portuguese racial identity and by describing how this formation informs present-day racial thought in Portugal.
\end{abstract}

A curious juxtaposition between image and text in one of the posters created by the commission in charge of the commemoration of the five hundredth anniversary of the Portuguese maritime discoveries (Comissão Nacional Para As Comemoraçōes Dos Descobrimentos Portugueses) encapsulates this essay's central concern: the historical roots of the formation of Portuguese racial identity. The image [fig. 1], an illustration from the Livro de Lisuarte de Abreu (ca. 1558-1564), represents a war scene in Sri Lanka and includes details such as burning buildings, half-naked warriors with bows and arrows as well as spears, soldiers with firearms (including cannons), and several bleeding, fallen

THE JOURNAL FOR EARLY MODERN CULTURAL STUDIES VOL.11, NO. 1 (SPRING/SUMMER 2011) (C) 2011 


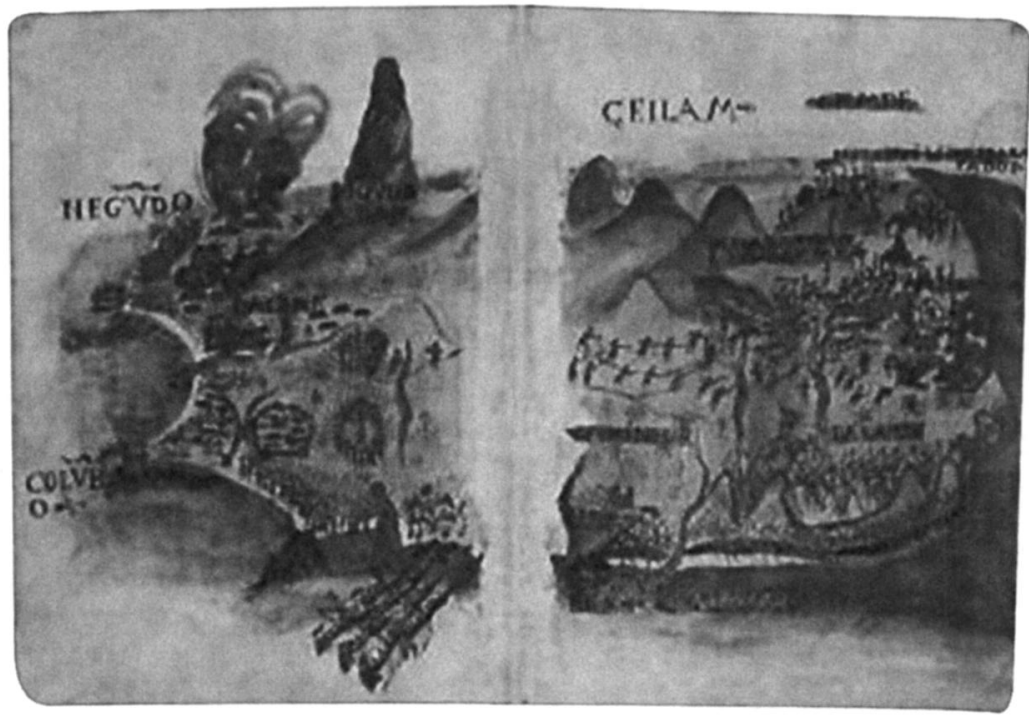

Fig. 1. Illustration from the Livro de Lisuarte de Abreu (ca. 1558-1564).

bodies. Given the presence of a few buildings marked as Christian churches by the crosses on top, it is possible to infer that the scene refers to a time when the Portuguese had already established a presence in Colombo, the Sri Lankan capital here depicted. Their role in this particular scene seems to be that of allies to one Sri Lankan kingdom against the forces of another. As represented in the illustration, the Portuguese and their firearms are instrumental in the defeat of the king who attacked Colombo.

In the early sixteenth century, several Sri Lankan kings did, indeed, form alliances with the newly arrived Portuguese in order to maintain their power against other kings (de Silva, "Islands" 286); thus, in this respect, the illustration is not particularly curious. Its juxtaposition with a text that completely ignores the war scene printed right beside it, however, gives one pause. The short note that accompanies the image offers general information on the early modern Portuguese presence in India and highlights the positive interactions between them and the peoples they encountered:

The coast of India was reconnoitred by the Portuguese early in the $16^{\text {th }}$ century. Impossible to obtain in Calicut, good relations were nevertheless established with Cochin and Cananor. In 1510 Goa was conquered, becoming the capital of the "State of India"... 
Thousands of Portuguese settled all through the East, where marriage to Indian women became a frequent practice. Among their main occupations the achievement of a very profitable trading activity between the different regions of Asia deserves special mention. ("Portuguese Travels")

No mention is made of the violence underlying the Portuguese presence in the East, even though it is well documented in contemporary chronicles; only a euphemistic "Goa was conquered" offers a slight qualification to the more attractive picture of "marriage to Indian women" and successful commercial relations. ${ }^{1}$

The text's elision of the violence attendant on the conquests and its emphasis on the Portuguese capacity for cultural and social integration, while not exactly deceitful, is strategically indirect. Importantly, it reflects a wide, present-day Portuguese national perspective on the country's presence in the world since the mid-fifteenth century, evident in the impulse behind the recent tenyear celebration of the five hundredth anniversary of the discoveries: while the country, its government, and its people no longer necessarily hold the view that that presence was a mark of heroism and "owed" to the nation as a result of the superiority of its explorers and the vision of their leaders, the tendency continues to be to whitewash it enough for it to remain, with as little discomfort as possible, not only the historical moment that defined the Portuguese as a people, but also that which continues to make them proud. Nowhere is this more apparent than in the section of the program of the Portuguese $\mathrm{XI}^{\text {th }}$ Constitutional Government dedicated to planning the then-upcoming celebrations:

Até ao final do século comemorar-se-á o quinto centenário dos Descobrimentos portugueses. Para o efeito o X Governo nomeou uma comissão especialmente encarregada de estruturar um programa que, uma vez aprovado, será cometido às entidades executivas adequadas.

As comemorações não constarão somente de cerimónias formais. A intenção principal é mostrar ao Mundo e, especialmente, aos Portugueses o que foi uma grande operação científica, organizada de modo eficaz, mobilizando os conhecimentos ao tempo mais avançados e contribuindo simultaneamente para o desbravar do Mundo e da Ciência. As consequências económicas, sociais, políticas, culturais e científicas dos Descobrimentos Portugueses assumem uma importância tão grande para o conjunto da humanidade que os descendentes dos seus autores não podem 
deixar de os estudar, aprofundando os seus conhecimentos, e de sublinhar o papel decisivo que eles tiveram para o progresso.

Todas as vertentes dos Descobrimentos são importantes, mas são aquelas que hoje nos podem servir de inspiração para um novo estímulo do nosso processo de desenvolvimento e para a mobilização dos portugueses, em especial dos jovens, que devem ser as mais enaltecidas: em particular, $o$ papel fulcral do espírito científico em toda a operação, a facilidade de estabelecimento de relaçóes com todos os povos e a extraordinária aptidão para a mediação entre culturas diversas que os Portuguesas exibem. ("Programa do XI Governo" 78)

Until the end of the century, the five hundredth anniversary of the Portuguese Discoveries will be commemorated. To that effect, the roth Government nominated a commission especially charged with elaborating a program which, once approved, will be submitted to the appropriate executive entities.

The commemorations will not be entirely constituted by formal ceremonies. The main intention is to show the world, and especially the Portuguese, what was a great scientific operation, efficiently organized, mobilizing the most advanced knowledge of the time and contributing, at the same time, to opening up the World and Science. The economic, social, political, cultural, and scientific consequences of the Discoveries for the whole of humanity are so vast that the descendants of their authors cannot but study them in order to deepen their understanding of them and to underline the decisive role they had in advancing progress.

All aspects of the Discoveries are important, but the ones that can inspire and stimulate our development and mobilize the Portuguese, the youth in particular, should be most ennobled; namely, the central role of the scientific spirit in the entire operation, the facility in establishing relations with all peoples, and the extraordinary aptitude exbibited by the Portuguese for mediation between different cultures. (emphasis added) ${ }^{2}$

As the previous excerpt shows, the idea that the Portuguese have a special ability to relate to, and mingle with, other peoples and cultures has remained a part of the national ideology, its perpetuation allowing us to frame as somewhat benign five centuries of imperialism that included the slave trade and colonial rule. ${ }^{3}$ The old saying that the last generation of colonialists was 
still fond of repeating-"God created blacks and whites; the Portuguese created mulattoes" - clearly captures the problematic nature of Portugal's attempt at upholding the view of the history of its five-century presence in the world as one of integration rather than one of domination; it also invites the interrogation of the present-day Portuguese view of the country as a white nation. For after five centuries of "establishing relations" with peoples all over the world, after "marriage to Indian women" and "peaceful integration into Muslim cultures" ("Portuguese Travels"), after even claiming to having "created mulattoes," the Portuguese still think of themselves as a white people. ${ }^{4}$ This essay analyzes the origins and development of this disjunctive perception as reflected in key texts of the literature of the Portuguese discoveries and in the context of the nation's history.

Eduardo Lourenço, a celebrated Portuguese essayist, philosopher, and cultural critic who has written extensively about Portuguese cultural history, argues that the country's cultural identity is deeply imbricated in the notion of a special destiny-one implicitly tied to its glorious past. In the essay "Portugal Como Destino," he follows other thinkers in seeing the "national trauma" of the loss of independence to Spain in 1580 - after the defeat of the Portuguese army and the death of King Dom Sebastião in North Africa, in the battle of Alcazar-Kebir on August 4, 1578-as having had a powerful impact on the nation's unconscious and having led to the development of the myth that in the future, Portugal would recover its glory as a new empire. Announced by the Jesuit Father António Vieira after the loss of independence in the late sixteenth century, the Fifth-Empire, as it was called, was to be an Empire of the Spirit, blessed by Christ (Lourenço, "Portugal Como Destino" 12-21). The myth survived in the culture: reiterated and rearticulated in the late 1920 and 1930 s by the poet Fernando Pessoa in a number of essays as well as in his book of poems, Mensagem (1935) (Serrão 45-46; Pessoa 223); exploited by the Salazar ideology, the New State, in order to foster nationalist fervor (Lourenço, "Psicanálise" $3 \mathrm{I}$ ); and surfacing in a less systematic manner roughly a decade after the April 1974 revolution (Da Silva 154), it helped shore up the nation's fragile belief in itself.

This fragile belief survived in part due to what Lourenço sees as a marked characteristic of the Portuguese people-"o irrealismo prodigioso da imagem que os portugueses fazem de si mesmos" ("the prodigious unrealism of the image they have of themselves"; "Psicanálise" 19). Rooted in paradoxical beliefs, i.e., in "consciência de uma congenital fraqueza e a convicção mágica duma 
protecção [divina] absoluta" ("a sense of a congenital weakness and a magical conviction of an absolute [divine] protection") as well as in "conjunção de um complexo de inferioridade e superioridade" ("the conjunction of an inferiority and a superiority complex"), this unrealistic image enabled us, the Portuguese, "a esconder de nós mesmos a nossa autêntica situação" ("to hide from ourselves our real situation"; 21). Apart from a brief interregnum, the problematic premise that Portugal's glorious past should be the anchor of its identity remained unquestioned: "a consciência nacional ... a nossa razão de ser, a raís de toda a esperança, era o termos sido. ... O viver nacional orienta-se nessa época para um futuro de antemão utópico pela mediação primordial, obsessiva, do passado" ("the national consciousness ... our reason for being, the root of all our hopes, rested on what we had been. ... National life focused on a future proleptically utopian because obsessively mediated by the past"; 25 ). ${ }^{5}$

Arguably, that is still the case to this day. Even though the nationalist ideology promoted by the Salazar regime was, since the April 1974 revolution, denounced and for the most part overcome, the attempts at a politically correct articulation of Portugal's historical impact in the world reveal the extent of the country's continued reliance on its imperial past to give meaning to its present. The length of the celebration of the discoveries (a decade) and the tone of the government's statement about it cited earlier in this essay belie the success of attempts at rethinking Portuguese identity. Indeed, Lourenço stresses that the opportunity presented by these attempts, undertaken by scholars such as João Medina, António Quadros, and José Augusto Seabra, was essentially wasted. In the aftermath of the disintegration of the African colonial enterprise in 1975, Lourenço maintains, it was "urgente, de facto, repensar ... a totalidade da nossa aventura histórica" ("urgent, indeed, to rethink ... the totality of our historical adventure"; "Repensar Portugal" 74). But that never happened. As a result, he stresses, the images in the Portuguese collective memory, positive and negative alike, are not "o resultado de um exame aprofundado da realidade portuguesa em todos os seus aspectos, mas o resultado do reflexo politico-ideológico ... [de] motivações patrióticas" ("the result of a profound examination of the Portuguese reality in all its aspects; rather, they are the ideological result of provocative patriotic motivations"; 77).

That there is a non-pathological way to articulate the meaning of Portugal's past in relation to its present Lourenço does not deny. In fact, in some of his latest work he has insisted on the distinction between living with our past as if it were "uma mascara dourada de impotência presente" ("a golden mask to cover 
our present powerlessness"; "Nós Como Futuro" 21 ), foreswearing it under the compulsion of post-revolutionary ideological pressures ("Portugal Como Destino" 77), and revisiting it seriously (7I). This essay is in the spirit of the serious revisitation of Portugal's historical and cultural legacy advocated by Lourenço, even though its ultimate goal of explaining the process of Portuguese racial formation has never been a concern of his. ${ }^{6}$ For while Lourenço's insightful analyses of Portuguese history and culture offer no explicit reflections on race, they nevertheless represent an important context for discussing the issue of Portuguese racial identity. As this essay argues, the very historical elements he sees as having determined, from the late medieval period on, the key traits of the Portuguese national character are the same that conjoined to form the country's white racial identity - an identity that remains firmly part of the national consciousness. By looking at the historical circumstances of the formation of the Portuguese nation, and by going back to the time of the first significant Portuguese interactions with the non-Western world, this essay seeks to identify crucial elements of the formation of Portuguese racial identity and to highlight the extent to which those elements continue to be present in the nation's political unconscious and to influence the Portuguese notion of themselves as a people.

\section{National Identity Formation}

Studies of collective identity formation repeatedly emphasize the importance of the role played by "the other" in that process. In Uses of the Other: "The East" in European Identity Formation (1999), Iver B. Neumann acknowledges "the limits of the self-other perspectives" (xvi) but insists that they yield important insights. Among these insights he underscores two key realizations: since the existence of the self is tied to the existence of an other, the other is constitutive of the self; and the role of other can be filled by different entities at different historical moments (4I). In the particular case of medieval Europe, he points out, the Moors fulfilled that role; thus, the identity of European peoples was primarily religious-they identified as Christians. A European identity as such only began to form and to overtake a Christian one after the Crusades, as Renaissance princes turned increasingly to national concerns (43-48).

In the case of Portugal, this development is especially noteworthy: not only was Portugal the first country in Europe to become a unified nation-state (in II4O, at a time when Spain, for example, was a group of separate kingdoms still to be unified), but, once it did, it also embarked on the process of expanding its 
borders to its present-day area by conquering the land that had been occupied by the Moors.? For the Portuguese, then, the process of nation formation was inextricably connected to and even fostered by their Christian identity. ${ }^{8}$ When, in the early Renaissance, the Portuguese began incursions into North-African port towns (Ceuta, for example, was conquered in 1415), and then farther and farther south along the west coast of Africa, until finally they rounded the Cape of Good Hope and sailed up the Indian Ocean along the east coast of Africa to reach India (1498), the religious motivation and the national aggrandizement motivation coincided: Christ was behind the birth of the Portuguese nation; therefore, the success of Portugal's maritime expansion could only underscore the nation's sense of itself as elected. ${ }^{9}$

The profound effect of the discoveries in the formation of Portuguese national identity cannot be overstated. Because they happened so early in the nation's existence, and because they came to an end within a century and a half, they created a huge, enduring gap between the country's "mitologia da antiga nação gloriosa" ("mythology as ancient glorious nation") and its "diminuida realidade presente" ("present diminished reality"; Lourenço, "Psicanálise" 3I). Living in the past became the defense mechanism developed by the nation to deal with the psychic trauma: by having lived for centuries as the people who "descobri[u] e baptiz[ou] a Terra, de Cabo Verde à Índia, do estreito de Magalhães às Filipinas" ("discovered and baptized the Earth, from Cape Verde to India, from the Strait of Magellan to the Philippines"; Lourenço, "Identidade e Memória" II), the Portuguese forestalled having to confront significant cultural and historical traumas. ${ }^{10}$ But besides shielding the nation's psyche from trauma by allowing it to remain in denial, this obsession with the past also suggests that the nation arrested the development of its identity at the moment of the discoveries. The Portuguese went from identifying as Christian heroes fighting the Moors at the time of the birth of the nation to Christian heroes claiming the rest of the world for their Christian nation. "After that, nothing could quite measure up, so potentially different identities failed to evolve. When, at rare moments in its history, the need to confront the decadence of the nation emerged, the emblematic moment of the discoveries resurfaced as the anchor of any argument for future greatness. As the poet Fernando Pessoa noted at the time of the transition between the deeply unstable First Republic (1910-1926) and Salazar's New State regime (1932-1968), the discoveries proved that Portugal could attain greatness again. He saw the Portuguese as "um grande povo de heróis adiados" ("a great people of postponed heroes"; 79) and 
viewed the discoveries as "um acto cultural ... um acto de criação civilizacional ("a cultural act ... an act of civilization"). "Criámos o mundo moderno" ("We created the modern world"; 223), he declared.

Pessoa's claim that the discoveries were "an act of civilization" and that through them the Portuguese "created the modern world" is particularly sug. gestive in the context of this argument. Indeed, in a way he most likely did not intend, this claim hints that Portugal's obsession with the discoveries may have one implication for the country's racial identity formation that still needs to be explored: with the discoveries, the Portuguese connected parts of the world that had not been connected before and fostered increased interaction between cultures. This interaction created the conditions for the emergence of particular perceptions of Western cultural superiority that led, in part, to the development of the concept of race (as distinct from skin color) as it survives today. From this perspective, then, Pessoa's claim that the Portuguese "created the modern world" can be read as implying that since the development of the modern world is connected to the development of the idea of race, the Portuguese were instrumental in facilitating the emergence of the concept..$^{12}$

Historical evidence seems to bear out this interpretation. Most historians of race now agree that race as we understand it today is "a mental category of modernity" (534) to use Anibal Quijano's apt expression. Explanations for the development of this differentiating category stress the powerful ideological implications of the term, implications not always evoked by a distinction based on phenotype (skin color), but that eventually attached to it. ${ }^{13}$ However, the difference between conclusions reached by studies from Iberian and Anglo-American perspectives needs addressing. For if Quijano's view that "the invention of the category of 'color'-first as the most visible indication of race and later simply as its equivalent - as much as the invention of the particular category of 'white,' still requires a more exhaustive historical investigation" (574n5) is undeniable, his hypothesis that "they are most probably Anglo-American inventions since there are no traces of these categories in the chronicles and other documents from the first one hundred years of Iberian colonialism in America" (574n5) needs refining. A look at Portuguese documents challenges this generalization, as well as the contention that Iberians "never thought of them [Africans] in racial terms before the colonization of America. ... [that] race as a category was applied for the first time to the Indians, not to blacks. ... [and that] race appears much earlier than color in the history of the social classification of the global population" (574n5). ${ }^{14}$ 
Indeed, fifteenth- and sixteenth-century Portuguese chronicles of encounters with Moors in northern Africa, with Black Africans along both coasts of the continent, as well as with Indians, Sri Lankans and other peoples in the Far East, repeatedly note skin color as a differentiating element, just as much as they do in chronicles of the first encounters with the Amerindians of Brazil, reached in 1500. Zurara classified the Africans that were brought to Portugal in 1444 to be sold at auction according to color: "Among them there were some of reasonable whiteness, handsome, and ... others less white, sort of brown [the word used is "pardos"], others as black as Ethiopians, as ugly in face as in body." ${ }^{15} \mathrm{~A}$ distinction between white and black Moors is repeatedly noted in chronicles of the $1400{ }^{16}$ In turn, Giovanni da Empoli, in his famous letter about the Portuguese presence in Asia in the early 1500s, describes people encountered while he was aboard a Portuguese ship near Sumatra as "white men; they dress like us in German fashion, with boots and French shoes; they come from a very cold land because their territories lie towards the North Pole" (132). Tomé Pires, in his Suma Oriental (ca. 1516), describes the Persians as "men of our colour" (22); "The people of Malabar are black and some of them dark brown" (67); "Most of the Bengalees are sleek, handsome black men" (88); "The people of China are white. As white as we are" (116); and he records the comparison made by Malays between the Portuguese and the Llequjos: "there is no difference between the Portuguese and the Llequjos, except that the Portuguese buy women, which the Lle[quj]os do not.... The Llequjos ... are white men" (130). Finally, in another document about the encounter between the Portuguese and the Malaccans, the latter reportedly said of the Portuguese, "These are white Bengalis" (Reid 275).

As the examples above demonstrate, color was well established as a differentiating element before the colonization of America and its use was, if not always, at least largely descriptive-i.e., not overwritten with the ideological connotations that were soon to attach to it through the process of racialization (which involved the imposition of hierarchical values on the color differences between peoples in relations of domination). ${ }^{17}$ Quijano is right in maintaining that "race and racial identity were established as instruments of basic social classification" (534). As he explains,

Terms such as Spanish and Portuguese, and much later European, which until then indicated only geographic origin or country of origin, acquired from then on a racial connotation in reference to the new identities. Insofar 
as the social relations that were being configured were relations of domination, such identities were constitutive of the hierarchies, places, and corresponding social roles, and consequently of the model of colonial domination that was being imposed. (534)

In the process of racialization, Quijano argues, skin color became emblematic of those identities: "[a]s time went by, the colonizers codified the phenotypic trait of the colonized as color, and they assumed it as an emblematic characteristic of racial category" (534). But this process, as we will see, happened earlier than he hypothesizes, and originated in the Iberian world, rather than in the "area of Anglo-America," as he suggests. ${ }^{18}$

There are several studies that shed light on the process through which there came to be hierarchical implications to color differentiation in the Iberian Peninsula in general, and in Portugal and its area of influence in particular. In his essay "A Imagem do Africano pelos Portugueses antes dos Contactos," Luís Horta argues that in Portugal, negative medieval stereotypes associated with blackness carry into the beginning of the fifteenth century, before actual contact with African peoples beyond the northern regions of the continent, but that these begin to disappear with the rise of a religious distinction between Moors (black or white, but Islamic; thus enemies) and other Africans (black but Gentiles; thus potential Christian converts) (62-63).

However, in "Iberian Expansion and the Issue of Black Slavery: Changing Portuguese Attitudes, 1440-I770," A.J.R. Russell-Wood shows that the Portuguese view of themselves as having "an unusual capacity for assimilating and tolerating other races" is qualified by the evidence (38). He mentions Zurara's account of the arrival of the first African slaves in Lagos, as well as a few instances from literary representations of black characters, in order to demonstrate that there was strong prejudice based on skin color $(38-40) \cdot{ }^{19} \mathrm{He}$ further points out that while contemporary Portuguese chroniclers such as Zurara and João de Barros appear sensible of the injustice and cruelty involved in the African slave trade (3I-34), the effects of the official ideology shoring up the Portuguese expansion were such that despite political and theological debates and doubts (34-38), the use of black slaves in Portugal and in the plantations of Madeira and Brazil became established by the early sixteenth century (33). ${ }^{20}$

James Sweet's seminal essay “The Iberian Roots of American Racist Thought" offers compelling evidence of the development of a racial ideology in the Iberian world well before the colonization of America. His argument that 
"the racism that came to characterize American slavery was well established in cultural and religious attitudes in Spain and Portugal by the fifteenth century" and that "racist beliefs ... were firmly entrenched before Christopher Columbus made landfall in the Americas" (144) has subsequently been expanded by other scholars, most recently in the collection of essays edited by Margaret R. Greer et al., Rereading the Black Legend: the Discourse of Religious and Racial Difference in the Renaissance Empires. As Sweet points out and these other studies corroborate, the meaning of the term "race" in the fifteenth century referred to "a shared genealogy" and did not have the ideological connotations it has today (Sweet 144). ${ }^{21}$ But in equating race (as "a shared genealogy") with culture, and in upholding cultural hierarchies, Sweet writes, early modern Europeans believed that "a people's inferior culture implied a biologically inferior people. Behavioral patterns and lifeways that Europeans viewed as aberrant were linked to genetically fixed qualities-especially phenotype and skin color" (144). Once that correspondence was established, it was not possible for the culturally othered to transcend their inferior status because the biological marker of that status could not change, even if religious and cultural behaviors could and often did (145). In other words, "'when differences that might otherwise be considered ethnocultural are regarded as innate, indelible, and unchangeable ... a racist attitude or ideology can be said to exist"' (Fredrickson qtd. in Greer et al. 13).

In tracing the historical process through which skin color became, for Iberians, the marker of cultural superiority or inferiority, Sweet stresses the discrimination against black slaves practiced in the Muslim world from as early as the eighth century (145-49). As he argues, "Muslims came to view slavery as the condition that best suited sub-Saharan Africans" and "[o]ver time, Iberian Christians ... adopted the same sets of symbols and myths, with additional arguments. Not only were blacks not Christians, but they were the Muslims' servants, the heathen's heathen, doubly cursed by their status as non-believers and by their servile condition" (149). ${ }^{22}$ In addition, he emphasizes that gradations of skin color from black sub-Saharan Africans to "tawny-colored Muslims," to white Iberian Christians led to a "refined and sharpened" "perception of difference" (149) that translated into a cultural hierarchy in which whiteness was superior. ${ }^{23}$ The ultimate result of this process was the formation of a coherent Iberian racist ideology (I62), which Sweet goes on to call "racism without race" ( 165 ) because in the fifteenth century classification of individuals "according to race was not ... common" ( 165$)$. But, I would argue, this distinction is 
primarily one of degree. As he concludes, "[e]ven though a fully developed ideology of race was not articulated, fifteenth-century white Iberians made distinctions among peoples based on skin color and attributed less worth to human beings who had black or brown skins. ... For people of any color but white, life's possibilities were severely circumscribed" (165-66).

Strong evidence of how close to "racialization" the terms of the relationships between whites and non-whites were already at this time is the "legalized inferiority" that began to take shape in the late fifteenth century. ${ }^{24}$ Kate Lowe points out in "The Black African Presence in Renaissance Europe" that Portugal came up, from early on, with specific legislation to address the high numbers of black African slaves in the country:

in Portugal under King Manuel, new legal codes were introduced aimed specifically at legislating for circumstances arising from the new influx and population of slaves. The royal legislation on slavery enacted between I48I and 1514 was collected and included in the Ordenaçōes Manuelinas, first published in 1514, with a definitive edition of 1521. (7)

As her argument suggests, legislating "cultural differentiation" probably attempted to clarify what must have been, at least in part, an elusive concept for the Portuguese and other Europeans:

\begin{abstract}
"blackness" proved a slippery concept for Europeans who already believed that some of their own numbers (for example, Southern Italians) were dark-skinned and consequently less than ideal. There were many gradations of "white" just as there were many varieties of "black," and classification of these often subtle differences could be challenging. (II)
\end{abstract}

Lowe goes on to posit that the period's intense focus on "blackness" might have led Europeans to consider the meaning of their "whiteness" as well, though her study does not pursue this insight. But Anu Korhonen's essay in the same volume reminds us that "race is a cultural, historical concept, born out of the needs of a specific period in time to define the 'other' that needed containing" (I12, emphasis added). For the Portuguese, then, the articulation of a "refined and sharpened" notion of color suggests the need to establish more perceivable color boundaries between themselves and the peoples that they "othered," and to do so because those boundaries were not as sharp 
physically as they were culturally. The detailed classifications that emerged in Portuguese India to distinguish between those of European origin and birth (reinois) from those of European origin born in India (castiços), or from those of mixed blood (mestiços), for example, indicate the social importance these gradations of whiteness held. Unsurprisingly, "the mestiços were looked down upon by those of 'pure' blood" (Subrahmanyam 220).

Portuguese identification with whiteness dates from the early period of the formation of that racial category: the ideology of cultural superiority that attached to the discoveries ("an act of civilization" through which "we created the modern world," as Pessoa argued) and which justified first the enslavement, and later the colonization, of "uncivilized" peoples, made that identification all but inevitable. Yet, as the process of maritime expansion progressed and the Portuguese increasingly mixed with the peoples they encountered, "the darkening of Portuguese whiteness" (Boxer qtd. in Blackmore 24) was repeatedly raised. As early as 1596, with the publication, by the Dutch Jan Huygen van Linschoten, of a narrative of his travels in Portuguese India (The voyage of John Huyghen van Linschoten to the East Indies), there is textual evidence of an interpretation of Portuguese interracial relations as instrumental in bringing about the decline of the people and the empire. As Carmen Nocentelli points out, Linschoten's work openly connected the decadence of Portuguese Asia to "the progressive entanglement of European settlers into Indian life" (209) and to "a blurring of ethnoracial distinctions . . . locate[d] . . in the sexual traffic between European men and Asian women" (212). The powerful influence of Indian culture on Europeans who were more than willing to adopt Asian ways is interpreted by Linschoten as ultimately leading to the erasure of the Portuguese race: children of Portuguese born in India (not of mixed race) are described as already revealing somatic traces of "Indianization" in a passage that suggests that it is not 'through intermarriage [that] the Portuguese 'race' is progressively phagocytosed and eventually erased, but rather ... that such erasure may occur even in the absence of interracial mingling" (Nocentelli 215$){ }^{26}$

The discussion, initiated with Linschoten's narrative, of the negative impact on the Portuguese of their sexual and non-sexual mingling with the peoples they encountered continued to be echoed in later works. Both Lisa Voigt and Nocentelli have stressed how late nineteenth-century historians typically reiterated this interpretation. Voigt writes: "In 1899, R. S. Whiteway attributed to the Portuguese 'an alacrity not found in other European nations, to mix their race with others differing entirely in status from themselves.' He 
characterized the resulting 'deterioration in the Portuguese race' as one of the 'moral causes' ... of the decline of the Portugese Empire in the East Indies" (Writing Captivity 13). In turn, Nocentelli notes how nineteenth-century "Orientalists of various stripes concurred that the Portuguese had only themselves to blame for this decline, as at its very root was their peculiar penchant for racial and cultural mixing" (205). ${ }^{27}$

Given these views, it is not surprising that the position where the Portuguese were eventually placed in the racial hierarchies being formed in Europe was quite different from where they had placed themselves. ${ }^{28}$ But their claim to "whiteness," based as it was on the ideology of cultural superiority that attached to the discoveries, and which depended on a process of hierarchical differentiation between themselves and the Africans, Asians, and Amerindians they came in contact with, has been recorded in the chronicles of those encounters. The following analysis of two contemporary accounts of the initial Portuguese contact with those cultures illustrates the process of formation of Portuguese whiteness and illuminates how the ideology of cultural superiority that allowed for that racial formation has been reinterpreted and restated in such ways that it has remained an essential part of the nation's present-day identity.

\section{Textual Representations}

Two of the best-known studies of narratives of early encounters between Europeans and Native Americans-Tzvetan Todorov's The Conquest of America (1982) and Stephen Greenblatt's Marvelous Possessions (1991) - remark on the problem of the reliability of those accounts; they also identify "wonder" (Greenblatt 23) and "enchantment" (Todorov 36) as central elements in "the early modern discourse of discovery" (Greenblatt 23). For Todorov, "enchantment" is tied to "the discovery self makes of the other" (3), while for Greenblatt, "wonder" both signals and produces two contrasting attitudes toward the "other": it can be "a sign of the eyewitness's surprising recognition of the other in himself; himself in the other," or it can be "at war with itself," causing, on the one hand, an "uneasy perception of the similitudes hidden in otherness," and on the other, "preventing the perception of the other as brother" (25). In the records of early Portuguese interactions with peoples of the non-Western world under consideration, both "enchantment" and "wonder" are at work. They are important tropes in the textual representation, and thus in the construction, of Portuguese racial identity. They reveal that representations of the 
"other," whether inflected by enchantment and wonder, or fear and distrustand always oscillating between identification with, and rejection of, that other-ultimately betray the limitations of a perception overdetermined by an unacknowledged intuition that the "other" often reveals the self to itself. In the Relação by Álvaro Velho (chronicling the first voyage of Vasco da Gama to India in 1497-98), and in the Carta by Pêro Vaz de Caminha (relating Pedro Álvares Cabral's discovery of Brazil in 1500), there are striking instances of this pervasive ambiguity: the self embracing its recognition in the other, only to eventually repress and deny that recognition. ${ }^{29}$

Some of the historians who most recently have looked at those and other chronicles of early encounters remind us that in them "human alterity is simultaneously revealed and refused" (Ferronha 13 ). $3^{\circ}$ They also call attention to the "superficial" nature of the Portuguese connection to these "others" (Ferronha I0), and to their tendency to see "sobretudo aquilo que queriam ou que esperavam ver" ("mostly what they wanted or expected to see"; Loureiro, "O Encontro de Portugal" 168), repeatedly drawing parallels between the new things they encountered-from places, to flora and fauna, to people and their cultureand the things they already knew (Loureiro, "O Encontro de Portugal" 157-59; Newitt xix). ${ }^{31}$ Vasco da Gama and his crew famously mistook a Buddhist temple for a Christian church. ${ }^{32}$ Pêro Vaz de Caminha repeatedly evokes the Portuguese provinces of Douro and Minho to give the King an idea of the vegetation and the climate of Brazil (Caminha 19, 30); the records in João de Barros and Diogo do Couto's Da Ásia reveal that the Portuguese imagined the Congo as "a European-style monarchy with kings, dukes and counts" (Newitt xix). Such an inclination inevitably produced cultural misreadings that created tensions and sometimes led to violence. ${ }^{33}$ More importantly, however, this tendency to read the other via the self is a crucial element in the formation of Portuguese racial whiteness because the distancing gesture that follows the moment of identification with the other performs a hierarchical differentiation that sharpens the perception of difference: I am not like the other.

Of the place and people encountered the very first time Vasco da Gama's ships touch land (on the West coast of Africa), Velho writes:

Nesta terra há homens baços, que não comem senão lobos-marinhos e baleias e carne de gazelas e raízes de ervas; e andam cobertos com peles $e$ trazem uma bainha em suas naturas ... e têm muitos cães, como os de Portugal, e assim mesmo ladram. As aves desta terra são assim mesmo 
como as de Portugal: corvos-marinhos, gaivotas, rolas, cotovias e outras muitas aves. (12)

In this land there are dark men who eat nothing but sea-lions, whales, and the flesh of gazelles and the roots of grasses; and they cover themselves with skins and they have their natural organs in a pouch ... and they have many dogs, like the ones from Portugal, that bark just the same. The birds of this land are like the ones from Portugal: cormorants, seagulls, doves, mocking-birds and many other birds.

And he continues:

Ao outro dia ... saimos em terra com o capitão-mor e tomámos um homem daqueles, o qual era pequeno de corpo e se parecia com Sancho Mexia ...e levámo-lo à nau do capitão-mor, o qual o pôs consigo à mesa, e de tudo que nós comíamos, comia ele. E ao outro dia o capitão-mor o vestiu muito bem e o mandou pôr em terra. (12-13)

The following day ... we went ashore with the captain and seized one of those men, who was of small build and resembled Sancho Mexia ... and we took him aboard the captain's ship, who sat him at his table, and of all we ate, he ate too. And the day after, the captain had him dressed properly and taken ashore.

The passages illustrate rather clearly the tendency to read the things newly encountered via analogy - the dogs and the birds are the same as those in Portugal, and even the man they seize resembles a fellow crewman. But difference is noted first and emphasized more strongly: the men are dark, they eat things the Portuguese do not, and they dress in skins. Thus, while the act of sitting the man at the captain's table and of dressing him "properly" might signal recognition of the self in the other, the fact that he had been forcefully seized and taken aboard preempted any serious contemplation of that recognition.

Tellingly, despite being among people they do not know, the Portuguese do not imagine themselves to be at a disadvantage: their attitude toward the inhabitants they encountered betrays the hierarchical differentiation that they immediately established based on the notion of their own culture as superior. ${ }^{34}$ When, later on, they are forced to run for their lives from a group of natives, 
Velho's narrative reveals that it was precisely a sense of superiority that led the Portuguese to leave their ships unarmed:

e os negros começaram de correr ao longo da praia ... eles nos começaram a atirar com umas azagaias que traziam, onde foi ferido o capitão-mor e três ou quarto homens. $E$ isto porque nos fiámos neles, parecendo-nos que eram homens de pequeno coração e que não se atreveriam a cometer o que depois fizeram, pelo que íamos despercebidos de armas. (14)

and the blacks began to run along the beach ... and began to shoot some arrows that they carried, whereby the captain and three or four other men were wounded. And this because we trusted them, as they seemed men of little courage who would not dare to do what they did after all, which was the reason we were not carrying arms.

They learn not to underestimate the potential danger presented by the people they encounter, and as the trip progresses around the Cape of Good Hope and up the East African coast, the crew only comes ashore "muito bem armados" ("very well armed"; 16). Still, Velho's narrative gives plenty of evidence of a patronizing attitude toward the different black cultures they encounter: for instance, they trade objects they deem worthless for ivory (17); the chronicler registers surprise at the beautiful music the Africans play-"concertavam muito bem para negros, de que se não espera música" ("they played very well for blacks, of whom one does not expect music"; 17); the crew use cannons just as a show of force, and the fright and confusion of the natives is described in a deprecating tone-"e eles estavam todos assentados na praia junto com o mato; $e$, quando ouviram desfechar as bombardas, começaram de fugir tão rijo para o mato que as peles, com que andavam cobertos, e as armas lhes ficavam" ("they were all sitting on the beach near the forest; and when they heard the cannons, they began running towards the forest, so hard that the skins that covered them, and the weapons, remained behind"; 19). Every aspect of the contactwhether commercial, artistic, or military-is represented in hierarchical terms that depend on and reinforce established correspondences between color and level of civilization. As such, they contribute to sharpening the differentiation between the Portuguese and the others.

Symptomatic of the racial implications of this differentiation is the lesspatronizing attitude toward the lighter-skinned Muslims and "white Moors" 
the Portuguese encounter farther up the coast. Velho's description emphasizes the richness of the clothes, as well as the value of the merchandise they have for trading:

Os homens desta terra são ruivos e de bons corpos e de seita de Mafamede e falam como mouros; e as suas vestiduras são de panos de linho e de algodão, muto delgados e de muitas cores de listras, e são ricos e lavrados; e todos trazem toucas nas cabeças, com vivos de seda lavrados com fio de ouro; e são mercadores e tratam com mouros brancos, dos quais estavam aqui, em este lugar, quarto navios deles que traziam ouro, prata e pano e cravo e pimenta e gengibre e anéis de prata com muitas pérolas e aljôfar e rubis. (28-29)

The men of this land are tawny and of good bodies, and of the Muslim sect, and they speak like Moors; and their clothes are of fine and colorful linen and cotton cloth, rich and embroidered, and all have caps in their heads with silk piping embroidered with gold; and they are merchants and they deal with white Moors, of whom there were here four ships carrying gold, silver, and cloth and clove and pepper and ginger and silver rings with many pearls and seed-pearls and rubies.

There is suspicion in the interactions, which follow the then-traditional pattern of antagonism between Christians and Muslims, and the Portuguese end up using force. Significantly, the textual representation of the fighting depicts the Portuguese as the stronger party with the stronger weapons, and the Moors retreat and run away. But the gesture of differentiation being performed in these dealings with a culture they perceive as more advanced than that of the sub-Saharan Africans they had encountered earlier emphasizes religion more than it does race: "depois que jantamos, fomos com os batéis a ver se podiamos tomar alguns deles, para por eles havermos dois cristãos índios que tinham cativos" ("after dinner, we went with the boats to see if we could apprehend some of them, so that we could exchange them for two Indian Christians they were holding captive"; 35$)$.

It would be tedious to mention all the instances in the text when Velho refers to the Portuguese hopes of finding Christians in those lands, especially since scholars have noted them repeatedly. "Cristãos e especiaria" ("Christians and spice") is the often-cited Portuguese answer to the question of what they 
were seeking in India (Velho 51). What the passages discussed make abundantly clear and the analysis above highlights is that in Velho's chronicle, whenever an interaction with Muslim cultures that are perceived as more advanced is concerned, if peaceful trading cannot be obtained or maintained, religious difference becomes the organizing trope of the narrative of the conflict. ${ }^{35}$ In the case of interactions with sub-Saharan cultures-again, cultures perceived as inferior in terms of civilization-the patronizing and belittling tone of the narrative is deployed as a rhetorical aid to a differentiation dependent on and reinforcing of the hierarchical implications of color.

An analogous pattern of differentiation emerges in the narrative of the discovery of Brazil: in his Carta, Caminha focuses on the particular aspects of the people the Portuguese encounter that make them other - their color, their nakedness, their piercings, and their head gear, among other things. He writes:

A feição deles é serem pardos, maneira d'avermelhados, de bons rostos e bons narizes, bem feitos. Andam nus, sem nenhuma cobertura, nem estimam nenhuma cousa cobrir nem mostrar suas vergonhas. E estão acerca disso com tanta inocência como têm em mostrar o rosto. Traziam ambos os beiços de baixo furados e metido por ele um osso branco de comprimento de uma mão travessa e de grossura dum fuso d'algodão e agudo na ponta como furador.... Os cabelos seus são corredios e andavam tosquiados de tosquia alta mais que de sobre-pente, de boa grandura e rapados até por cima das orelhas. E um deles trazia ... uma maneira de cabeleira de penas de ave amarela, que seria de comprimento dum coto, mui basta e mui çarrada que lhe cobria o toutiço $e$ as orelhas, a qual andava pegada nos cabelos, pena e pena, com uma confeição branda como cera e não o era. (7-8)

Their way is to be dark, sort of reddish, of good faces and good noses, well made. They are naked, without any covering, nor do they care to cover their modesty. And they are as innocent about it as they are about showing their faces. Both had their lower lips pierced and through them had a white bone of the sideways length of a hand, and the thickness of a cotton spool and pointy in the extremity like a piercer.... Their hair is straight and of good length and shaved to above the ears. One of them had ... feathers of a yellow bird, very densely and thickly covering his head and ears, and which were glued to the hair, feather by feather, with something like wax, but not. 
As had been the case during the Vasco da Gama voyage, the crew brings two natives aboard the captain's ship. Still emphasizing difference, Caminha stresses how much they disliked the food they were served:

Deram-lhes ali de comer pão e pescado cozido, confeitos, fartéis, mel e figos passados; não quiseram comer daquilo quase nada. E alguma cousa, se a provavam, lançavam-na logo fora. Trouxeram-lhes vinho por uma taça, mal lhe puseram a boca e não gostaram dele nada e nem o quiseram mais. (9)

They were given bread and cooked fish, sweets and cakes, honey and dried figs; there was almost nothing they wanted to eat. And if they tasted something, they would spit it out immediately. They brought them a tumbler of wine, they barely tasted it and did not like it at all and did not want it again.

The insistence on their nakedness and innocence, reiterated throughout the narrative in a tone of wonder and admiration, suggests the narrator's positive feelings for these people whom he sees as living very close to nature. At one point he calls them "gente bestial e de pouco saber e por isso são assim esquivos" ("wild people, of little knowledge, which is why they are so coy"; 19), but he immediately adds that

eles, porém, com tudo, andam muito bem curados e muito limpos e naquilo me parece ainda mais que são como aves ou alimárias montesas que lhes faz $\mathrm{o}$ ar melhor pena e melhor cabelo que às mansas, porque os corpos seus são tão limpos e tão gordos e tão formosos, que não pode mais ser. $\mathrm{E}$ isto me faz presumir que não têm casas nem moradas em que se acolham. E o ar, a que se criam, os faz tais. Nem nós ainda até agora não vimos nenhumas casas nem maneira delas. (19)

they take very good care of themselves and are very clean and so it seems to me that they are more like birds or beasts of the mountain for whom the open air is better than for the domestic ones, because their bodies are as clean and plump and beautiful as possible. And this makes me presume they have neither houses nor shelters. And the open air in which they are raised makes them thus. Nor have we till now seen any houses, nor the like. 
The representation of the life of the Amerindians as Edenic is the organizing trope of the narrative and informs all aspects of the chronicler's depiction of their interaction with the Portuguese. Its peaceful quality is underscored first: they exchange small presents almost daily (II); the natives help with replenishing the ships' water and wood reserves (24); the interaction becomes increasingly closer as they arrive at the beach each day with fewer and fewer bows and arrows and stand closer to the crewmen, eventually allowing physical touch $(18-20)$. Thus, for the greater part of this short narrative, the stress is on the beneficent aspects of the cultural exchange, the initial emphasis on difference giving way to remarks subtly suggesting sameness: a few days after the Portuguese arrived, two of the natives came aboard one of the ships where they "comeram toda vianda que lhes deram. E mandou-lhes fazer cama de lençóis ... E dormiram e folgaram aquela noute" ("ate all the food they were given. And a bed with sheets was prepared ... and they slept and enjoyed that night"; 23); the following day, at the beach, the Amerindians joined the crewmen in eating of their food, and some actually drank wine (24); close to the end of the Portuguese stay, the number of overnight visitors to the ships increases and they are described as feeling comfortable wearing shirts, sleeping in mattresses and sheets, and eating what food they are given (26-28).

But the perception (and representation) of sameness is tenuous and immediately rejected, followed as it is by a gesture of hierarchical differentiation performed through a rhetorical equation of closeness to nature with cultural inferiority. ${ }^{36}$ For if Caminha comments positively on that closeness, he does so patronizingly, emphasizing what he sees as simple-mindedness and readiness to be influenced: as the Portuguese stay comes close to the end, the captain and the crewmen gather by the large cross they had erected on the beach, kneel by it, and kiss it. When they invite a few Amerindians to do the same, "e foram todos logo beijá-la" ("they all immediately went to kiss it"; 25). The inference the chronicler makes from the Amerindian's mimicry of the Portuguese gestures of worship performs the movement from sameness to hierarchical differentiation that is central to the formation of Portuguese racial identity. Caminha writes:

Parece-me gente de tal inocência que, se os homens entendesse e eles a nós, que seriam logo cristãos, porque eles não têm nem entendem em nenhuma crença, segundo parece. $\mathrm{E}$, portanto, se os degredados que aqui hão-de ficar aprenderem bem a sua fala e os entenderem, não duvido... fazerem-se 
cristãos e crerem na nossa fé, à qual praza Nosso Senhor que os traga, porque certo esta gente é boa e de boa simplicidade e imprimir-se-á ligeiramente neles qualquer cunbo que lhes quiserem dar. (25, emphasis added)

They seem to be people of such innocence that, if we understood them and they us, they would immediately become Christian, because they do not have any beliefs, as it seems. And therefore if the transported convicts we will leave here come to learn their language and to understand them, I doubt not ... they will be made Christian and will believe our holy faith, if it be Our Lord's will, for certainly these people are good and simple and any influence can quickly be imprinted in them.

As he details the manner in which the natives imitate the gestures of the crewmen at mass (27-28), describes the way many agree to have pendants with tin crosses hung around their necks (28), and reiterates his impression that they will be easily converted to Christianity - "segundo o que a mim e a todos pareceu esta gente não lhes falece outra cousa para ser toda cristã que entenderem-nos, porque assim tomavam aquilo que nos viam fazer, como nós mesmos, por onde pareceu a todos que nenhuma idolatria nem adoração têm" ("according to what seems to me and to all, these people need only to understand us to become Christian, for they did everything as we did, and thus seem to have no idolatry or worship"; 28 [emphasis added])-Caminha actually highlights difference, rather than sameness. For in mimicking the Portuguese, the Amerindians reveal precisely that they are not like the Portuguese; in stressing this distinction, Caminha performs a gesture of hierarchical differentiation that emphatically distances the Portuguese from this "other" perceived as tabula rasa, as people ready to be have "any influence ... imprinted in them" (25).37 As was the case with Velho's Relação, the Carta by Caminha reinforces established correspondences between color and level of civilization, and ultimately contributes to sharpening the differentiation between the Portuguese and the Amerindians. In their representation of these early modern encounters between civilizations, both texts help to shore up the ideology of cultural superiority that attached to the discoveries, and both participate in, even as they reveal, the process through which the Portuguese identification with, and conceptual formation of, whiteness is further reinforced by othering people of darker skin. 


\section{The "Necessity of Whiteness"}

That this early identification has survived until today can be explained in part by Portugal's "choice" of a European identity. The westernmost southernmost country in Europe, Portugal, for centuries, crafted its identity at the margins of a European one, focusing first on Asia, and later on Africa and South America, its alignment with whiteness sustained by the ideology of imperialism and colonialism. In Portugal Como Destino, Lourenço believes that the country's early alienation from Europe was precisely a result of its having become an empire, which made it insular and caused it to turn its back on Europe (17). But by the mid-nineteenth century, this isolation had actually become marginalization, he argues, and "uma nova geração ... descobre que não é Europeia, isto é, que não sente, nem conhece, nem pensa, nem cria como podia fazê-lo se estivesse 'realmente' nessa Europa que lhe envia as suas criaçooes e os ecos reais ou fantásticos ... da civilização, com maiúscula" ("a new generation discovered that it was not European; i.e., that it did not feel, nor know, nor think, nor create as it could if it 'really' were in that Europe that was sending back its creations and the echoes ... of Civilization with a capital C"; 36). A century and a half later, and by the efforts of "homens decididos" ("decisive men") who "em cada geração" ("generation after generation"; 58) sought to bring Portugal back to Europe, the Portuguese "por fim entrámos na Europa como se sempre lá tivessemos estado" ("finally joined Europe as if we had always been there"; 60).

But this choice, especially given the April 1974 revolution, was only one among several possibilities: as Lourenço has already pointed out, Portugal could have aligned itself instead with the Eastern bloc (by choosing to embrace Communism), or with Latin America (by choosing to emphasize a common language and common culture with Brazil). That it did not, that it chose Europe, in spite of-or maybe actually in response to-Europe's complicated racial attitude toward its South, further emphasizes the country's continued identification with whiteness. Deliberate or not, that choice should at least be noted. For as part of southern Europe, Portugal has had to confront gestures of hierarchical differentiation similar to those it performed toward the cultures it colonized. In "A South with a View: Europe and its Others" (2000), Robert Dainotto reflects on the significance of the current North/South divide for the European continent ${ }^{38} \mathrm{He}$ recalls the historical development of the meaning of Europe, from what Federico Chabot called "an essentially ethical category" (qtd. in Dainotto 377) that originally defined itself against despotic 
Asia, and thus depended on an "antithetical principle" for its identity (379), to an entity that seeks to find the "other" within itself "in order to theorize its own identity independently from any 'other'" (380). As Dainotto points out, Europe eventually has come to seek within itself "a supplement for what it is not" (380) and the European south has come to replace "the Orient" as Europe's "archeological past," as the origin that justifies Europe's sense of itself as an entity invested in an "infinite process of civilization-[a] teleological movement from what it was to what is now" (380). Part of the European south, and a country whose "glorious past" is long gone, Portugal has struggled with being, along with other southern countries, "an epistemologically colonized part of colonizing Europe" (38I). It is perhaps what finally explains the tone and length of the celebration of the five hundredth anniversary of the discoveries, ${ }^{39}$ and the unequivocal choice to finally "join" Europe: in an effort to reject any perception of cultural inferiority, Portugal has sought to consolidate its alignment with Europe and continues to identify as a "white culture," subordinating consideration of the multi-racial implications of its history to the perceived necessity of whiteness.

The celebration of the discoveries might have been an opportunity for the culture to re-examine that perception, an ideal moment for the country to take stock of the cultural legacies of that historical moment. But while a preoccupation with political correctness was openly expressed in the language of the official program - which emphasized the need to foreground "a reciprocidade da 'descoberta" ("the reciprocity of the 'discovery") and "enquadrar as descobertas portuguesas de modo a não ferir susceptibilidades" ("to frame the Portuguese discoveries in such a way as not to wound susceptibilities"), in particular those of "dos países africanos de expressão portuguesa" ("the African countries of Portuguese expression"; "Programa do XI" 2.15) - and while much scholarship about the encounters with African, Indian, and Amerindian peoples was published throughout the period, the country's excessively narrow sense of itself as a white nation remained unaddressed. This essay hopes to call attention to the ideological implications of the choice to leave the issue unrecognized. For while there are historical reasons that determined the Portuguese identification with whiteness early on in the formation of the nation, what constitutes the "Portuguese people" today, after centuries of Portuguese presence in the world, needs reassessment. ${ }^{40}$ 


\section{NOT E S}

I wish to offer thanks to the ODU Research Foundation for a summer grant to support the writing of this essay. See http://whitewash.digitalodu.com for a flash display of the multimedia project of which this essay is part.

1. For documentary evidence of the violence attendant upon the Portuguese maritime expansion, see especially Zurarás Crónica dos Feitos da Guiné (1453); Cadamostós Viagens de Luis de Cadamosto e Pedro de Cintra (1507); Velhós Relação da Viagem de Vasco da Gama (ca. 1500); Empoli's Letters (1514) and The Commentaries of the Great Afonso de Albuquerque (1576). Present-day scholarship also gives ample information about the extent to which the Portuguese presence overseas was, especially initially, shored up by arms (Albuquerque et al.; Reid 275). Though peaceful integration of many Portuguese into Muslim cultures in Asia did occur, sometimes through marriage to native women (Nocentelli 205; Reid 272-73; Voigt, Writing Captivity 13), as well as through conversion to Islam (Disney and Booth 3; Prakash 178), it should not be forgotten that the earliest encounters were violent, as the Portuguese attempted conquest and subjugation (Reid 275).

2. This and all subsequent citations from Portuguese sources are accompanied by my translations.

3. Indeed, as chronicled by Gomes Eanes de Zurara, the Portuguese were the first modern European slave traders; see also Earle and Lowe; Fonseca; Jordan; Lahon; Saunders. Moreover, Portugal was not only the first modern European country to establish overseas colonies, but also the last to give them up. Angola, Mozambique, and Guinea-Bissau attained independence in 1975, a year after the fall of the Portuguese fascist regime that had, for the last thirteen years of its near half-century hold on the country, waged an open war against African attempts at overthrowing colonial control.

4. While historians of Iberian culture have noted that "Iberian whiteness is not necessarily English or French whiteness" (Blackmore 24) and that in the early modern era many Iberians"who were white, 'but not quite"' (Branche 93), "fought to have their whiteness recognized and their African or Indian origin somehow overlooked or excused" (91), the issue has not, to my knowledge, been brought up in Portuguese discussions of national culture and identity.

5. According to Lourenço's reading of Portuguese cultural history, the one moment of exception to this self-delusion was the late nineteenth century, when a group of writers known as the Generation of 70 vigorously denounced the apathy and decadence of the culture ("Portugal Como Destino" 38).

6. In the essay "The Situation in Africa and the National Consciousness," Lourenço mentions in passing that "in some ways it is accurate to say that we were agents of a multiracial civilization," but only to urge us "not to engage in some childish inversion of the terms of the question by proclaiming that the multiracial civilization is our consciously conceptualized product when it is more accurate to say that the colonizer is the product of that civilization" (200). In other words, the Portuguese self-image as a special (benign) breed of colonizers needs correcting because "the distance between what we imagine ourselves to be and what we are is very great" (180). The salient issue here is, of course, that even as Lourenço critiques Portuguese delusions regarding the nation's colonial past, he remains unconscious of the startlingly "othering" effect of his words-which, of course, imply that the Portuguese "made" that "other" multiracial civilization, but that civilization is not our civilization.

7. For studies of the Moor as the religious and political "other" of the Portuguese, see Blackmore; Horta, "A Imagem do Africano"; Greer et al.; and Subrahmanyam. 
8. In fact, the notion eventually developed of the mystical origin of the nation as the victory of Dom Afonso Henriques and his army against five Moorish kings at the battle of Ourique in 1139 came to be associated with a miracle: according to legend, the day before the battle, Dom Afonso Henriques, then a count, had a vision of Christ, who told him he would win despite being greatly outnumbered by the Moors. His army did win, and he was enthusiastically proclaimed king. The association of the birth of the Portuguese nation with Christ's will was repeatedly emblematized in the national consciousness by the building of monuments commemorating the miracle, by the iconography of the national flag, and by its celebration in Luís de Camões's epic The Lusiads.

9. In "Identidade e Memória," Lourenço compares the Portuguese belief in being a chosen people to that of Jews, the difference being that "Portugal não espera o Messias, o Messias é o seu passado, convertido na mais consistente e obsessiva referência do seu presente" ("Portugal does not await the Messiah, the Messiah being its past, converted into the consistent and obsessive reference of its present"; 10). Elsewhere, he emphasizes the "esoterismo" ("esotericism") or "misticismo" ("mysticism") of a Portugal "portador secreto de uma mensagem ou pussuidor virtual de um Graal futuro" ("carrying a secret message or possessing a future Grail"; "Psicanálise Mítica" 38-39).

10. The permanent state of denial of the Portuguese nation is a recurrent theme in Lourenço's work. In "Psicanálise Mítica do Destino Português," he specifies that the process of decolonization in the mid- to late-1970s, for example, ought to have caused huge trauma to the nation, were it not for "a capacidade fantástica que em nós se tornou uma segunda natureza, de integrar sem problemas de consciência o que em geral provoca noutros povos dramas e tragédias implacáveis" ("the amazing capacity, which has become second nature to us, of integrating, without problems of conscience, what to other people would have been implacable dramas and tragedies"; 46).

11. In 1494 the Portuguese and the Spanish signed the Treaty of Tordesillas, sanctioned by papal bulls, which divided the until-then "undiscovered world" between the two Christian countries. For a thorough description of papal endorsement of the Portuguese imperial endeavors and of the religious impulse invoked to justify conquest and enslavement of "heathens," see Russell-Wood 25-32. His analysis of "the development of an official ideology to justify Portuguese commercial and military offensives in Africa and Asia" (30) is especially interesting in this context.

12. As noted earlier, the chronicles of Zurara show that the Portuguese first enslaved black Africans as early as 1441 (61-69; see also Russell-Wood 16 and 30-31). The first public sale of black slaves in the town of Lagos, in the south of Portugal, happened August 8, 1444 (Zurara 107-09; see also Russell-Wood 16, 30-31; and Lowe 10-11). While some scholars have argued that the enslavement of blacks was not the cause of the racial discrimination against them, others insist on a connection. See Allen; and Sweet. Here, it is important to stress the potential chronological coincidence of the emergence of the notion of race with the beginning of the enslavement of black Africans-and the Portuguese connection to both.

13. For concise overviews of scholarship on the development of the concept of raceand compelling arguments of their own-see Allen; Greer et al.; and Sweet. Allen reviews a considerable number of historians and their theories of the development of racism in North America. He is most persuaded by those who see it as a "solution to the problem of social control" (24) in early modern North America, by ensuring that the status of poor, EuropeanAmericans "depended not upon their property but upon their 'race" (19). He endorses the argument of Lerone Bennette Jr. that "a system of racial privileges for the propertyless 'whites' 
was deliberately instituted in order to align them on the side of the plantation bourgeoisie against the African-American bond-laborers" (21). And Allen points out that later, when "an emigrant population from 'multiracial' Europe goes to North America or South Africa and there, by constitutional fiat, incorporates itself as the 'white race,' that . . . is rather a political act: the invention of the white race" (22). This invention, moreover, demonstrates the "relativity of race" (24). In turn, Greer et al. call attention to the fact that in the Renaissance Iberian world "racism was subtended by religious differences" (1). Finally, Sweet's argument focuses on how skin color became the marker of cultural hierarchy-which led to the development of what we identify today as a racist ideology.

14. Mignolo sums up these different perspectives:

In western European countries, mainly in German and French scholarship, race is a concept that entered the vocabulary of the Western world during and after the Enlightenment. As such, race corresponds in time and in space with the New World order that emerged after the American Revolution in 1776 and the French Revolution in 1789. In Spanish (and Portuguese), in the Iberian Peninsula, and in Ibero-América, race is not taken to be an invention of the Enlightenment in the countries north of the Pyrenees, but of the Renaissance. (312)

15. See Zurara 107-08; Lowe 11; and Russell-Wood 38-39.

16. See Velho 23; Horta “A Imagem do Africano" 51; Annie Courteaux's "Sobre o Mouro como Sinónimo de Negro," cited in Horta, "A Imagem do Africano" 51n23; Sweet 150n25; Saunders xiii.

17. The use of color as a differentiating category is nevertheless a step toward the kind of "othering" involved in the process of racialization: "In a cultural moment when the concept of race had not yet emerged as a labeling device, skin color could act to define the borders of civility and barbarism" (Korhonen 95). Suggestively, in Colonialism and Race in Luso-Hispanic Literature, Branche singles out Zurara's chronicle as "occup [ying] an important place in the broader European master narrative of discovery, colonization, and the creation of a worldwide racial order" (34).

18. See Greer et al.: "The history of racism as we know it today began to be articulated right then, in the sixteenth century, and there, in the Atlantic world" (2).

19. In his 1963 study Race Relations in the Portuguese Colonial Empire, 1415-1825, Boxer had already emphasized the discrepancy between the respect for racial and cultural difference professed by the Portuguese and actual practice. He cites example after example of prejudice and discrimination in the Portuguese relations with West Africans, concluding: "the prevailing social pattern was (and is) one of conscious white superiority" (40). And yet, as Blackmore points out, the "continuum of color" in "Zurara's slavemarket presents the possibility of a somatic link between slave traders and slaves.... African darkness is not that different from Portuguese whiteness" (28).

20. Saunders's 1982 study A Social History of Black Slaves and Freedmen in Portugal, 1441-1555 offers a detailed discussion of the "legal and philosophical justifications of the [Portuguese] slave-trade" (35). Unsurprisingly, these justifications were prompted by "an uneasy conscience" (35) about enslaving people with whom they were not at war and who often accepted the Christian religion.

21. Several essays in Rereading the Black Legend develop this point ("Race in medieval Spain was not color coded ... but was defined as a descent group or lineage" [9], the editors write). See especially Burns; Fuchs; and Nirenberg. 
22. As we saw earlier in "A Imagem do Africano," Horta's view of Portuguese attitudes toward sub-Saharan blacks (once they encounter them in their own territories, in the fifteenth century) offers a suggestive counterpoint to Sweet's assertion that their status as "heathens" and "servants of heathens" would make them "doubly cursed."

23. In Race and History (1952), Lévi-Strauss opens his reflections on race with the assertion that to relegate different cultures and their institutions to the status of inferiority is a tendency of humans in general, "irrespective of race or civilization" (12). Accounts of the Portuguese encounters with ancient, highly sophisticated civilizations in the East show the scorn they endured in many of the interactions because their behavior was perceived as crude. For example, there is a famous scene in Fernão Mendes Pinto's Peregrinação in which five Portuguese guests of a Japanese nobleman are mocked for eating with their hands (708). But, as Lévi-Strauss emphasizes, ideas of cultural superiority rest on the adoption of specific elements as markers of that superiority (27-29). At this particular historical moment, territorial expansion and control of trade through naval power became the measure of superiority, and the Portuguese claimed it confidently. Given the parallel development of the correspondence of whiteness with superiority, the Portuguese claimed it as well.

24. For a thorough analysis of how legislation is instrumental in the formation of racial identities, see Terhanian. He addresses nineteenth- and early-twentieth-century laws in America, but the circumstances that led to the creation of those laws-i.e., an influx of "outsiders" whose race "needed" to be established-are analogous to those in fifteenthcentury Portugal.

25. "Nuances of racial difference in the Iberian Peninsula differed markedly from English, French, or Dutch accounts of it" (Fuchs 95). For further discussion of southern European notions of whiteness see also Branche, esp. 91-93; and Blackmore 24.

26. In "Colonizing the Colonizer: A Dutchman in the Ásia Portuguesa," Kamps's argument that Linschoten's narrative performs a kind of "redirect[ing] or doubl[ing] of the gaze, not by allowing the Indians to see the Portuguese but by allowing his stereotypical and often harsh assessments of the natives to reflect back onto the Portuguese" (163), further illuminates how early the literary representation of the Portuguese begins to approximate them to the people they colonized: "As we see the natives, so we see the colonizers" (163).

27. Subrahmanyam argues that such northern European interpretations of the decline of the Portuguese nation and its empire are part of an anachronistic historical practice that allows for the erasure of significant aspects of the past: "the divisions and cleavages of the past century and a half between nations and national cultures have an unfortunate way of imposing themselves on historians who are studying an earlier epoch" (273). As he stresses, historians aware of the spatial division that emerged between "south[ern] Europe, Africa, Latin America and Asia on the one hand, and northern Europe and North America on the other," feel compelled to establish a corresponding division in time: "The attempt to divide the European presence in Asia into two phases, before and after about 1620, is an attempt to establish just such a division.... [w] hile at the same time asserting the historical lack of significance of the sixteenth century as a phase of change in Asian or even Iberian history" (274).

28. The following passage from an eighteenth-century British source further reveals this disjunction:

The lower class of women in England, are remarkably fond of the blacks, for reasons too brutal to mention ... in the course of a few generations more, the English blood will become so contaminated with this mixture ... this alloy may spread so extensively, as even to reach the middle, and then the higher orders of the people, till the whole nation resembles the 
Portuguese and Moriscos in complexion of skin and baseness of mind. (Long 48-49, qtd. in Coleman 187n3)

29. I have specifically chosen to analyze Velho's and Caminha's chronicles because they are witness accounts and because they constitute some of the earliest and most important representations of first encounters. Blackmore calls Velho's Relaf̧äo "one of the most important fifteenth-century documents to combine the nautical rutter and historico-ethnographic description" and points out that it more than likely served as the basis for Fernão Lopes de Castanheda's História do descobrimento e da conquista da India pelos Portugueses "and, probably through Castanheda, reached Camões" (57). Of Caminha's Carta, Voigt reminds us that "Historians and literary critics alike have interpreted the letter as not only the nation's [Brazil's] 'birth certificate' but one that attests to a painless delivery" ("Por Andarmos Todos Casy Mesturados" 407).

30. There is, of course, a wealth of other contemporary texts about the Portuguese maritime expansion. See Condicionantes Culturais da Literatura de Viagens, especially the essays by Horta ("O Africano"), Azevedo ("O Indio Brasileiro"), and Loureiro ("Visōes da Ásia"), for extensive information on Portuguese textual production about contact with Africa, South America, and Asia between the fifteenth and the seventeenth centuries. In addition, see Portuguese Encounters with Sri Lanka and the Maldives: Translated Texts from the Age of the Discoveries by Chandra Richard de Silva for an edition that juxtaposes Portuguese and Sri Lankan textual representations of these early contacts. Given that studies of the "discoveries" have mostly discussed Western texts, de Silva's edition can provide an important counterpoint. For as Raman has pointed out in his discussion of Camōes's Os Lusiadas, the poem-and, I would add, other Portuguese contemporary chronicles and fictional narratives-reveals "a renarrativization of the (multiple) histories of the East. [They] increasingly assign ... the possibility of an adequate representation of colonial lands to the European civilizers, and begin ... to replace 'native' histories with [their] own representations of these histories" ("Back to the Future" 143), with the result that " the brutality of colonial history assumes the mantle of heroic inevitability" (145). For an analysis of this renarrativization process specifically in the context of Africa, see Blackmore, who analyzes "the Portuguese textual fashionings of Africa and its people" (xv).

31. Since "the formation of the self is inextricably intertwined with the formation of its others and ... a failure to regard the others in their own right must necessarily have repercussions for the formation of the self" (Neumann 35), this attitude of seeing only what they wanted to see suggests that today's lack of self-awareness in the culture may have originated in the relations with the "other" established during these first encounters (see the discussion of Lourenço's analysis of Portuguese culture in the earlier part of this essay).

32. See Velho 55-56; Castanheda 46-47; De Silva, "Beyond the Cape" 299; and Loureiro, "O Encontro de Portugal" 159.

33. De Silva, for example, offers a comprehensive analysis of the cultural clashes between the Portuguese and the peoples of the Indian Ocean in "Beyond the Cape: the Portuguese Encounter with the peoples of South Asia."

34. As we saw in Sweet's essay, early modern Europeans came to attach notions of cultural superiority or inferiority to specific phenotypes (144).

35. This pattern recurs in the narrative of the rest of the voyage until the Portuguese arrive in Calicut, where it becomes exacerbated as they discover the strong position Muslim traders already held in India.

36. Critical reception of the Carta has traditionally emphasized those passages that represent the "intermingling" of the Portuguese sailors and the Brazilian natives as proof "of 
the distinctive benevolence of Portuguese colonization" (Voigt, "Por Andarmos Todos Casy Mesturados" 407). Here, I wish to highlight the ways in which Portuguese gestures of hierarchical differentiation systematically undermine what Voigt, in her reading of Caminha's chronicle, has called an "uncritical celebration of 'intermingling"' (408), which constructs that encounter as unproblematically happy.

37. Voigt's reading of Caminha's chronicle should be mentioned again in this context since it points out that, unlike "the accounts of Columbus and other early modern travel writers... [the Carta] does not so easily suppress the interactive and improvisational dimensions of intercultural contact, the ways that indigenous actors participated in and shaped the encounter" (424). The text may ostensibly represent the natives as eminently colonizable, but in places" it permits us to imagine other agencies that are either underplayed in or absent from the narrative" (424).

38. My thanks to Joanna Eleftheriou for bringing Dainotto's essay to my attention.

39. For details of the different aspects of the celebration of the Portuguese Discoveries, from the formation in late 1986 of a commission in charge of planning the commemorative program to the controversy that developed around the commemorations and the attempts "to reconcile different currents of opinion," see Oliveira's "The Scientific Activity of the CNCDP: A Preliminary Assessment." See also the plans for the celebrations elaborated in "Comemoraçōes dos Decobrimentos: Programa" and "Plano de Acçōes a Médio Prazo," both edited by CNCDP.

40. There is a considerable amount of scholarship on the racial formation of whiteness and the ideological significance of "choosing" whiteness. Besides Allen's The Invention of the White Race and Neumann's Uses of the Other: the East in European Identity Formation, discussed above, works that in some way inform this essay and first led me to think about Portuguese racial formation are: Joseph Cosco's Imagining Italians: The Clash of Romance and Race in American Perceptions, 1880-1910; David Gerber's "Caucasians are Made and Not Born: How European Immigrants Became White People"; Thomas Guglielmo's White on Arrival: Italians, Race, Color, and Power in Chicago, 1890-1945; Matthew Jacobson's Whiteness of a Different Color: European Immigrants and the Alchemy of Race; Aliza Wong's Race and the Nation in Liberal Italy, 1861-1911: Meridionalism, Empire and Diaspora; Robyn Wiegman's "Whiteness Studies and the Paradox of Particularity"; Susan Koshy's "Morphing Race into Ethnicity: Asian Americans and Critical Transformations of Whiteness"; David Roediger's "Whiteness and its Complications"; and Noel Ignatiev's How the Irish Became White. But two critics in particular influenced my conclusions: Richard Rodriguez and Ronald Takaki. Rodriguez's book Brown: the Last Discovery of America (2002), with its insistence on the importance of "the freedom to admit brown" (142) in the context of an American culture long invested in maintaining a sharp Black/White divide, suggested to me what needs to be discussed in the context of a Portuguese culture tethered to the necessity of whiteness. In turn, Takaki's A Different Mirror (1993) - a study of race in the United States that stresses the problems of the excessively narrow definitions, offered by the "established scholarship," of what constitutes the American people-led me to reflect on the analogous situation of Portuguese culture.

\section{Works Cited}

Abreu, Lisuarte de. Livro de Lisuarte de Abreu. Lisboa: Comissão Nacional para as Comemoraçōes dos Descobrimentos Portugueses, 1992.

Albuquerque, Afonso de. The Commentaries of the Great Afonso Dalboquerque. Ed. Walter de Gray Birch. New York: Burt Franklin, 1970. 
Albuquerque, Luís de et al. O Confronto do Olbar: o Encontro dos Povos na época das Navegaçōes Portuguesas. Lisboa: Caminho, 1991.

Allen, Theodore W. The Invention of the White Race: Vol. I: Racial Oppression and Social Control. New York: Verso, 1994.

Azevedo, Ana Maria de. "O f́ndio Brasileiro (o "olhar" quinhentista e seiscentista)." Condicionantes Culturais da Literatura de Viagem. Ed. Fernando Cristóvão. Lisboa: Cosmos, 1999. 305-35.

Barros, João de, et al. Da Asia de João de Barros e de Diogo do Couto. Lisboa: Regia officina typografica, 1777 .

Blackmore, Josiah. Moorings: Portuguese Expansion and the Writing of Africa. Minneapolis: U of Minnesota P, 2009.

Boxer, C. R. Race Relations in the Portuguese Colonial Empire, 1415-1825. Oxford: Clarendon, 1963.

- The Portuguese Seaborne Empire, 1415-1825. London: Hutchinson, 1969.

Branche, Jerome C. Colonialism and Race in Luso-Hispanic Literature. Columbia: U of Missouri P, 2006.

Burns, Kathryn. "Unfixing Race." Rereading the Black Legend: The Discourses of Religious and Racial Difference in the Renaissance Empires. Ed. Margaret R. Greer et al. Chicago: U of Chicago $\mathrm{P}, 2007$. 188-202.

Caminha, Pêro Vaz de. A Carta de Pêro Vaz de Caminha. Lisboa: CNCDP, 2000.

Castanheda, Fernão Lopes de. História do descobrimento e da conquista da India pelos Portugueses. Porto: Lello e Irmão, 1979.

Cristóvão, Fernando, ed. Condicionantes Culturais da Literatura de Viagens, Lisboa: Cosmos, 1999.

Coleman, Deirdre. "Janet Schaw and the Complexions of Empire." Eighteenth-Century Studies 36.2 (2003): 169-93.

"Comemorações dos Descobrimentos: Programa." Lisboa: CNCDP, n.d.

Dainotto, Robert. "A South with a View: Europe and its Others." Nepantla: Views from Soutb 1.2 (2000): 375-90.

De Silva, Chandra Richard. "Beyond the Cape: The Portuguese Encounter with the Peoples of South Asia." Implicit Understandings: Observing, Reporting, and Reflecting on the Encounters Between Europeans and Other Peoples in the Early Modern Era. Ed. Stuart B. Schwartz. Cambridge: Cambridge UP, 1994. 295-322.

-. "Islands and Beaches: Indigenous Relations with the Portuguese in Sri Lanka after Vasco da Gama." Vasco da Gama and the Linking of Europe and Asia. Ed. Anthony Disney and Emily Booth. New Delhi: Oxford UP, 2000. 280-94.

- ed. Portuguese Encounters with Sri Lanka and the Maldives: Translated Texts from the Age of the Discoveries. New York: Ashgate, 2009.

Disney, Anthony and Emily Booth. Introduction. Vasco da Gama and the Linking of Europe and Asia. Ed. Anthony Disney and Emily Booth. New Delhi: Oxford UP, 2000. I-7.

Empoli, Giovanni da. Lettera di Giovanni da Empoli. Ed. A. Bausani. Roma: Centro Italiano di Cultura, 1970.

Ferronha, António Luís. "Introdução." O Confronto do Olhar: o Encontro dos Povos na Epoca das Navegações Portuguesas. Ed. Luís de Albuquerque et al. Lisboa: Caminho, 1991. 9-25.

Fonseca, Jorge. "Black Africans in Portugal during Cleynaert's Visit (1533-1538)." Black Africans in Renaissance Europe. Ed. T. F. Earle and K. J. P. Lowe. Cambridge: Cambridge UP, 2005. II3-2I. 
Fuchs, Barbara. "The Spanish Race." Rereading the Black Legend: The Discourses of Religious and Racial Difference in the Renaissance Empires. Ed. Margaret R. Greer et al. Chicago: U of Chicago P, 2007. 88-98.

Greenblatt, Stephen. Marvelous Possessions: The Wonder of the New World. Chicago: U of Chicago P, 1991.

Horta, José da Silva. "A imagem do Africano pelos Portugueses antes dos Contactos." O Confronto do Olhar: o Encontro dos Povos na Epoca das Navegaçōes Portuguesas. Ed. Luís de Albuquerque et al. Lisboa: Caminho, 1991. 43-69.

"O Africano: produção textual e representações (séculos XV-XVII)." Condicionantes Culturais da Literatura de Viagens. Ed. Fernando Cristóvão. Lisboa: Cosmos, 1999. 26I-30I.

Jordan, Annemarie. "Images of Empire: Slaves in the Lisbon Household and Court of Catherine of Austria." Black Africans in Renaissance Europe. Ed. T. F. Earle and K. J. P. Lowe. Cambridge: Cambridge UP, 2005. 155-80.

Kamps, Ivo. "Colonizing the Colonizer: A Dutchman in Ásia Portuguesa." Travel Knowledge: European "Discoveries" in the Early Modern Period. Ed. Ivo Kamps and Jyotsna G. Singh. New York: Palgrave, 2001. 160-83.

Korhonen, Anu. "Washing the Ethiopian White: Conceptualising Black Skin in Renaissance England." Black Africans in Renaissance Europe. Ed. T. F. Earle and K. J. P. Lowe. Cambridge: Cambridge UP, 2005. 94-112.

Lahon, Didier. "Black African Slaves and Freedmen in Portugal during the Renaissance: Creating a New Pattern of Reality." Black Africans in Renaissance Europe. Ed. T. F. Earle and K. J. P. Lowe. Cambridge: Cambridge UP, 2005. 26I-79.

Lévi-Strauss, Claude. Race and History. Paris: UNESCO, 1952.

[Long, Edward]. A Planter. Candid Reflections upon the Judgement lately awarded by the Court of the King's Bench, in Westminster-Hall, on what is commonly called the Negroecause. London: T. Lowndes, 1772.

Loureiro, Rui. “O Encontro de Portugal com a Ásia no século XVI." O Confronto do Olhar: o Encontro dos Povos na Época das Navegações Portuguesas. Ed. Luís Albuquerque et al. Lisboa: Caminho, 1991. 155-211. . "Visōes da Ásia (séculos XVI e XVII)." Condicionantes Culturais da Literatura de Viagens. Ed. Fernando Cristóvão. Lisboa: Cosmos, 1999. 339-53.

Lourenço, Eduardo. "Identidade e Memória: o Caso Português." Nós e a Europa ou as Duas Razóes. Lisboa: Casa da Moeda, 1988. 9-16.

Nós como Futuro. Lisboa: Assírio e Alvim, 1998.

. O Labirinto da Saudade: Psicanálise Mitica do Destino Português. Lisboa: Dom Quixote, 1978.

Portugal como Destino Seguido de Mitologia da Saudade. Lisboa: Gradiva, 1969.

"Psicanálise Mítica do Destino Português." O Labirinto da Saudade: Psicanálise Mítica do Destino Português. Lisboa: Dom Quixote, 1978. 19-68.

. "Repensar Portugal." O Labirinto da Saudade: Psicanálise Mítica do Destino Português. Lisboa: Dom Quixote, 1978.69-84.

- "The Situation in Africa and the National Consciousness." This Little Lusitanean House: Essays on Portuguese Culture. Ed., trans., intro. Ronald W. Sousa. Providence: Gávea-Brown, 2003. 167-203.

Lowe, Kate. "Introduction: The Black African Presence in Renaissance Europe." Black Africans in Renaissance Europe. Ed. T. F. Earle and K. J. P. Lowe. Cambridge: Cambridge UP, 2005. I-14. 
Mignolo, Walter D. "What does the Black Legend Have to do with Race?" Rereading the Black Legend: The Discourses of Religious and Racial Difference in the Renaissance Empires. Ed. Margaret R. Greer et al. Chicago: U of Chicago P, 2007. 312-24.

Neumann, Iver B. Uses of the Other: "The East" in European Identity Formation. Minneapolis: U of Minnesota P, 1999.

Newitt, Malyn, ed. East Africa. Burlington, VT: Ashgate, 2002.

Nirenberg, David. "Race and the Middle Ages: the Case of Spain and its Jews." Rereading the Black Legend: The Discourses of Religious and Racial Difference in the Renaissance Empires. Ed. Margaret R. Greer et al. Chicago: U of Chicago P, 2007. 71-87.

Nocentelli, Carmen. "Discipline and Love: Linschoten and the Estado da India." Rereading the Black Legend: The Discourses of Religious and Racial Difference in the Renaissance Empires. Ed. Margaret R. Greer et al. Chicago: U of Chicago P, 2007. 205-24.

Oliveira, António de. "The Scientific Activity of the CNCDP: A Preliminary Assessment." E-Journal of Portuguese History 1.I (2003). Web. 12 Aug. 2008.

Pessoa, Fernando et al. Sobre Portugal: Introdução ao Problema Nacional. Lisboa: Ática, 1979.

Pinto, Fernão Mendes. Peregrinação. Lisboa: Casa da Moeda, 1998.

Pires, Tomé. A Suma Oriental de Tomé Pires e o Livro de Francisco Rodrigues. Ed. Armando Cortesão. Coimbra: Coimbra UP, 1978.

"Plano de Acçóes a Médio Prazo (1990-1995)." Lisbon: CNCDP, no date.

"Portuguese Travels and the Meeting of Civilizations-India and Ceylon." Poster nr. 16; text by José Manuel Garcia; trans. Jill Dias/Susana Silva. Lisbon: CNCDP, no date.

"Programa do XI Governo Constitucional." Web. 24 Oct. 2005. <http://www.portugal. gov.pt/pt/GCII/Documentos/GCil.pdf>

Prakash, Om. "The Portuguese in the Far East, 1540-1640." Vasco da Gama and the Linking of Europe and Asia. Ed. Anthony Disney and Emily Booth. New Delhi: Oxford UP, 2000). 13I-4I.

Quijano, Anibal. "Coloniality of Power, Eurocentrism, and Latin America." Nepantla: Views from South 1.3 (2000): 533-80.

Raman, Shankar. "Back to the Future: Forging History in Luís de Camões's Os Lusiadas." Travel Knowledge: European "Discoveries" in the Early Modern Period. Ed. Ivo Kamps and Jyotsna Singh. New York: Palgrave, 2001. 134-47.

- Framing "India": The Colonial Imaginary in Early Modern Culture. Stanford: Stanford UP, 2002.

Reid, Anthony. "Early Southeast Asian Categorizations of Europeans." Implicit Understandings: Observing, Reporting, and Reflecting on the Encounters Between Europeans and Other Peoples in the Early Modern Era. Ed. Stuart B. Schwartz. Cambridge: Cambridge U.P, 1994. 268-94.

Rodriguez, Richard. Brown: the Last Discovery of America. New York: Penguin, 2002.

Russell-Wood, A. J. R. "Iberian Expansion and the Issue of Black Slavery: Changing Portuguese Attitudes, 1440-1770." The American Historical Review 83.1 (1978): 16-42.

Saunders, A. C. de C. M. A Social History of Black Slaves and Freedmen in Portugal, 14411555. Cambridge: Cambridge UP, 1982.

Serrão, Joel. "Introdução." Sobre Portugal: Introdução ao Problema Nacional. Lisboa: Ática, 1979. 5-65.

Silva, Agostinho da. Ir à India sem Abandonar Portugal. Considerações. Outros Textos. Lisboa: Assírio e Alvim, 1994. 
Subrahmanyam, Sanjay. The Portuguese Empire in Asia, 1500-1700: a Political and Economic History. New York: Longman, 1993.

Sweet, James H. "The Iberian Roots of American Racist Thought." The William and Mary Quarterly 54.I (1997): 143-66.

Takaki, Ronald. A Different Mirror: a History of Multicultural America. Boston: Little, 1993.

Tehranian, John. "Performing Whiteness: Naturalization Litigation and the Construction of Racial Identity in America." The Yale Law Journal 109.4 (2000): 817-48.

Todorov, Tzvetan. The Conquest of America: The Question of the Other. Trans. Richard Howard. New York: Harper, 1984.

Velho, Álvaro. Relação da Viagem de Vasco da Gama. Introdução e notas de Luís de Albuquerque. Algueirão: Ministério da Educação, 1990.

Voigt, Lisa. "'Por Andarmos Todos Casy Mesturados': The Politics of Intermingling in Caminha's Carta and Colonial American Anthologies." Early American Literature 40.3 (2005): 407-39.

-Writing Captivity in the Early Modern Atlantic: Circulations of Knowledge and Authority in the Iberian and English Imperial Worlds. Chapel Hill: U of North Carolina P, 2009.

Zurara, Gomes Eanes de. Crónica dos Feitos Notáveis que se Passaram na Conquista de Guiné por Mandado do Infante D. Henrique. Lisboa: Academia Portuguesa da História, 1978. 